Vol. 2, No. 1, Desember 2021

\title{
PENDAMPINGAN IMPLEMENTASI KONSEP ENTITAS BISNIS PADA KELOMPOK USAHA BERSAMA (KUBE) DESA JAGARAGA
}

\author{
Susi Retna Cahyaningtyas \\ Fakultas Ekonomi dan Bisnis Universitas Mataram \\ susi_retnacahya@unram.ac.id \\ Rahmi Sri Ramadhani \\ Fakultas Ekonomi dan Bisnis Universitas Mataram \\ rahmisri.ramadhani@unram.ac.id \\ Zuhrotul Isnaini \\ Fakultas Ekonomi dan Bisnis Universitas Mataram \\ zuhrotul.isnaini@unram.ac.id
}

Info Artikel

Diterima:

01-11-2021

Direvisi:

24-12-2021

Diterbitkan:

24-12-2021

\begin{abstract}
Abstrak
Konsep entitas bisnis (business entity concept)

memandang bisnis sebagai entitas terpisah dari pemilik.

Prinsipnya, akuntansi tidak bisa digunakan oleh bisnis yang mencampur hartanya dengan harta pemilik. Konsep ini penting artinya dalam menilai keadaan keuangan dan hasil usaha yang dicapai suatu organisasi. Kegiatan pengabdian ini bertujuan untuk memberikan pemahaman konsep tersebut kepada dua Kelompok Usaha Bersama (KUBe) yang masing-masing kelompok beranggotakan 10 orang, dengan bidang usaha pembuatan stick pepaya. Metode yang digunakan adalah metode ceramah, tanya-jawab (diskusi) dan latihan penyelesaian kasus. Mekanisme pengabdian dilakukan dari rumah ke rumah dan jika diantara anggota kelompok tersebut rumahnya berdekatan maka dijadikan satu kelompok. Hal ini dilakukan karena dalam kondisi covid. Melalui kegiatan pengabdian ini para anggota KUBe dapat memahami dan menerapkan konsep entitas bisnis yang akan berdampak terhadap pengelolaaan usaha yang akuntabel, dan mampu memenuhi persyaratan untuk memperoleh bantuan dana dari Dinas Sosial.

Kata Kunci: pemilahan, harta pribadi, harta usaha
\end{abstract}

DOI: $10.29303 /$ abdimassangkabira.v2i1.66

\section{Pendahuluan}

Konsep entitas bisnis (business entity concept) adalah asumsi dasar akuntansi keuangan, karena konsep ini membatasi data ekonomi dalam sistem akuntansi ke data yang berhubungan langsung dengan aktivitas usaha. Dengan kata lain bisnis 
dipandang sebagai entitas terpisah dari pemilik, kreditor atau pihak pemangku kepentingan lainnya. Sebagai contoh, akuntan perusahaan perseorangan akan mencatat aktivitas-aktivitas bisnis saja, bukan aktivitas aset atau utang pribadi dari pemilik. Prinsipnya, akuntansi tidak bisa digunakan oleh bisnis yang mencampur hartanya dengan harta pemilik, (warren, 2017:7). Konsep yang paling mendasar di dalam akuntansi adalah entitas atau kesatuan usaha. Kesatuan usaha akuntansi adalah suatu organisasi atau bagian dari organisasi yang berdiri sendiri, terpisah dari organisasi lain atau individu lain. Ditinjau dari segi akuntansi, antara kesatuan usaha yang satu dengan kesatuan usaha yang lain atau dengan pemiliknya terdapat garis pemisah yang tegas. Ini berarti bahwa kejadian keuangan yang menyangkut kesatuan usaha, tidak boleh dicampur dengan kesatuan usaha lain atau dengan pemiliknya, dan sebaliknya. Konsep ini penting artinya dalam menilai keadaan keuangan dan hasil usaha yang dicapai suatu organisasi atau bagian dari organisasi. Tanpa konsep ini maka laporan keuangan akan menjadi kacau, karena apa yang tercantum dalam laporan keuangan suatu organisasi mungkin terdapat kejadian-kejadian keuangan yang sebenarnya tidak berhubungan dengan organisasi tersebut, (Jusup, 2011:15)

Kelompok Usaha Bersama (KUBe) merupakan kelompok keluarga miskin yang dibentuk, tumbuh, dan berkembang atas prakarsanya dalam melaksanakan Usaha Ekonomi Produktif (UEP) untuk meningkatkan pendapatan dan kesejahteraan sosial keluarga. Pengembangan kelompok KUBe merupakan program asistensi kesejahteraan sosial keluarga. Kementerian sosial mengeluarkan program bantuan, ditujukan untuk KUBe yang sudah memiliki embrio usaha dan sudah berjalan 1 (satu) tahun., memiliki struktur organisai, serta Rencana Anggaran Biaya (RAB).

Desa Jagaraga merupakan salah satu desa yang terdapat di kabupaten Lombok Barat Kecamatan Kuripan. Masih banyak masyarakat di desa tersebut yang mengandalkan mata pencaharian sebagai buruh tani, padahal sudah banyak bantuan dan program yang dianggarkan untuk memajukan daerah ini, namun belum maksimal bisa meningkatkan pendapatan masyarakat yang kurang mampu. Oleh karena itu perlu upaya yang lebih efektif untuk memajukan dan meningkatkan pendapatan masyarakat di daerah tersebut, melalui pembentukan Kelompok Usaha Bersama (KUBe). Pembentukan KUBe dimaksudkan agar masyarakat kurang mampu dapat mengembangkan usaha-usaha kecil sesuai dengan kapasitas yang dimiliki dalam rangka meningkatkan pendapatan ekonomi mereka. Di desa Jagaraga, terbentuk dua kelompok KUBe yang masing - masing kelompok beranggotakan 10 orang, dan telah mendapatkan pelatihan pembuatan produk stick papaya oleh mahasiswa KKN Universitas Mataram yang bertempat di desa tersebut. Pengolahan stick pepaya ini diharapkan dapat menambah penghasilan dan kebermanfaatan buah pepaya yang berlimpah di desa tersebut, yang selama ini hanya dijual begitu saja pada saat buahnya sudah matang. Usaha pembuatan stick pepaya belum bisa berlanjut karena keterbatasan modal yang dimiliki. Sementara untuk permohonan bantuan dana ke Dinas Sosial belum bisa dilakukan karena terkendala persyaratan.

Kegiatan pengabdian ini melakukan pendampingan implementasi konsep entitas bisnis agar para anggota KUBe memiliki pemahaman yang benar tentang konsep bisnis yang berdampak terhadap pengelolaan usaha secara akuntabel dan 


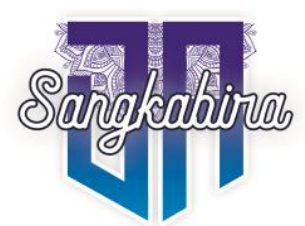

Vol. 2, No. 1, Desember 2021

mampu melakukan pemisahan antara harta pribadi dengan harta KUBe sebagai sebuah entitas bisnis. Jika usaha yang dilakukan benar-benar dikelola dengan baik, sesuai dengan prinsip akuntansi yang benar maka persyaratan dari Dinas Sosial dalam pengajuan bantuan dapat dipenuhi. Melalui Pengabdian ini juga diharapkan dapat memberikan dukungan dana agar KUBe mulai berproduksi dan memasarkan produk olahan stick papaya, sehingga bisa sebagai batu loncatan untuk memperoleh bantuan dana dari Dinas Sosial, yang mensyaratkan bahwa usaha sudah berjalan selama 1 (satu) tahun.

\section{Metode}

Metode yang digunakan untuk mencapai target luaran/output adalah metode partisipatif, yaitu suatu metode pembelajaran yang menempatkan peserta pengabdian sebagai pemain utama dalam setiap proses pembelajaran. Komponen pembelajaran ini mencakup dua hal yaitu pertama penyampaian materi dengan ceramah dan tanya jawab (diskusi), kedua adalah latihan penyelesaian kasus.

\begin{tabular}{|c|c|c|c|c|}
\hline $\begin{array}{l}\text { Mengubah pola pikir } \\
\text { kelompok KUBe } \\
\text { Desa Jagaraga agar } \\
\text { mengimplemnetasi } \\
\text { Konsep Entitas }\end{array}$ & $\Longrightarrow$ & $\begin{array}{c}\text { Melakukan } \\
\text { pendampingan } \\
\text { untuk } \\
\text { Mengimplementasi } \\
\text { kan Konsep Entitas }\end{array}$ & & $\begin{array}{c}\text { Pengimplentasian } \\
\text { Konsep Entitas Bisnis } \\
\text { pada Kelompok Kube } \\
\text { Desa Jagaraga }\end{array}$ \\
\hline
\end{tabular}

Gambar 1: Diagram Round Map

\section{Hasil}

Terdapat 2 kelompok KUBe di desa Jagaraga yaitu di dusun Tegal dan di dusun Dasan Geres. Masing-masing kelompok terdiri dari 10 orang sehingga total peserta sebanyak 20, akan tetapi hanya 18 orang yang bisa mengikuti kegiatan pengabdian ini. Pola pemberian materi menggunakan metode ceramah, tanya jawab dan juga diskusi yang disampaikan oleh tim dengan mekanisme dari rumah ke rumah dan jika diantara anggota kelompok tersebut rumahnya berdekatan maka dijadikan satu kelompok. Hal ini dilakukan karena dalam kondisi covid. Tim telah memberikan materi dan proses pendampingan tentang konsep entitas bisnis, yaitu suatu konsep yang melakukan pemilahan antara kekayaan pribadi dengan kekayaan perusahaan. Jika mendirikan suatu usaha perlu menerapkan konsep tersebut, agar terdapat pemilahan antara harta kekayaan pribadi dan perusahaan sehingga pencatatan perusahaan dapat dilakukan dengan benar. Jika sudah menerapkan konsep entitas bisnis maka langkah selanjutnya adalah mengidentifikasi aset-aset yang dimiliki oleh kelompok usaha tersebut termasuk setoran modal yang ada, sebagai dasar untuk menyusun neraca awal KUBe. Selanjutnya melakukan pencatataan setiap penerimaan dan pengeluaran yang terjadi secara kronologis berdasarkan urutaan waktu kejadiannnya. Semua hal tersebut diatas bisa dilakukan, jika dalam sebuah usaha ada yang mengkoordinir aktivitas usaha, dan diperlukan job description dari masing-masing bagian, sehingga disusun sebuah struktur organisasi. 


\section{Diskusi}

Salah satu prinsip dasar yang penting di akuntansi, khususnya dalam analisis transaksi prinsip kesatuan usaha (konsep entitas). Berdasar prinsip ini, pencatatan akuntansi yang dibuat oleh perusahaan harus dilihat dari sudut pandang perusahaan (Warsono, 2011:22). Penerapan konsep ini pada sebuah unit usaha, yaitu Kelompok Usaha Bersama (KUBe desa Jagaraga menjadi suatu hal yang penting. Berlandas pada prinsip kesatuan usaha, informasi akuntansi perusahaan menggambarkan kondisi dan kinerja keuangan perusahaan sebagai entitas yang berdiri sendiri.

\section{Kesimpulan}

Pengabdian ini bertujuan untuk memberikan pendampingan implementasi konsep entitas bisnis Kelompok Usaha Bersama (KUBe desa Jagaraga ). Kegiatan pengabdian ini berdampak pada pengelolaaan usaha yang akuntabel, sehingga KUBe tersebut dapat memenuhi persyaratan untuk memperoleh bantuan dana dari Dinas Sosial. Kementerian Sosial mengeluarkan program bantuan, ditujukan untuk KUBe yang sudah memiliki embrio usaha dan sudah berjalan 1 (satu) tahun., serta memiliki struktur organisasi, serta Rencana Anggaran Biaya (RAB).

\section{Pengakuan/Acknowledgements}

Pengabdian Kepada Masyarakat ini dapat terlaksana atas dukungan dari semua pihak, oleh karena itu kami mengucapkan terima kasih dan penghargaan kepada Dekan Fakultas Ekonomi dan Bisnis beserta jajarannya, Ketua Lembaga Penelitian dan Pengabdian kepada Masyarakat beserta jajarannya, Kepala Desa Jagaraga beserta jajarannya serta anggota kelompok KUBe yang ada di desa tersebut.

\section{Daftar Referensi}

Jusuf, AL.Haryono, 2002, Dasar-dasar Akuntansi Jilid I, STIE YKPN, Yogyakarta Soemarso S.R., 2004, Akuntansi Suatu Pengantar, Salemba Empat, Jakarta Warsono, Sony, 2011, Akuntansi Pengantar 1, penerbit ABPUBLISHER, Yogyakarta. Warren Carl S, Reeve James M, Duchac Jonathan E, Wahyuni Tri Ersa, Yusuf Abadi Amir, 2017, Pengantar Akuntansi 1, Salemba 4, Jakarta.

https://www.jurnal id. 2018

https://www. dictio.id ekonomi\&bisnis akuntansi 